San Jose State University

SJSU ScholarWorks

Master's Projects

Master's Theses and Graduate Research

Spring 2016

\title{
A Comparative Study of Urban Forest Management Programs for Three Major Cities in Santa Clara County: A Benchmarking Study
}

Suzanne Remien

San Jose State University

Follow this and additional works at: https://scholarworks.sjsu.edu/etd_projects

Part of the Environmental Policy Commons, Public Administration Commons, Urban Studies Commons, and the Urban Studies and Planning Commons

\section{Recommended Citation}

Remien, Suzanne, "A Comparative Study of Urban Forest Management Programs for Three Major Cities in Santa Clara County: A Benchmarking Study" (2016). Master's Projects. 469.

DOI: https://doi.org/10.31979/etd.5en3-v98v

https://scholarworks.sjsu.edu/etd_projects/469

This Master's Project is brought to you for free and open access by the Master's Theses and Graduate Research at SJSU ScholarWorks. It has been accepted for inclusion in Master's Projects by an authorized administrator of SJSU ScholarWorks. For more information, please contact scholarworks@sjsu.edu. 
A Comparative Study of Urban Forest Management Programs for Three Major Cities in Santa Clara County

A Benchmarking Study

by

Suzanne Remien

A Thesis Quality Research Paper Submitted in Partial Fulfillment of the Requirements for the Master Degree in

PUBLIC ADMINISTRATION

Prof. Frances Edwards, Ph.D.

The Graduate School

San Jose State University

May, 2016 


\section{Table of Contents}

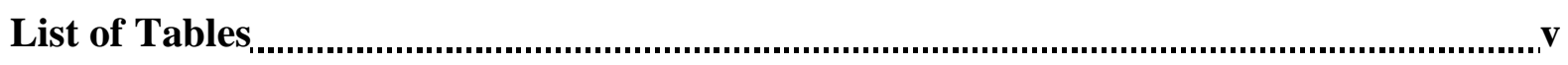

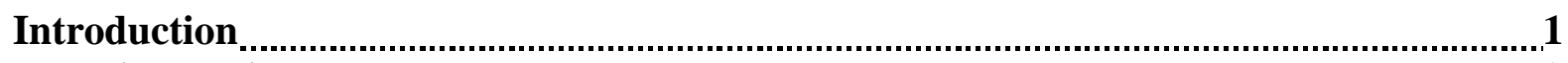

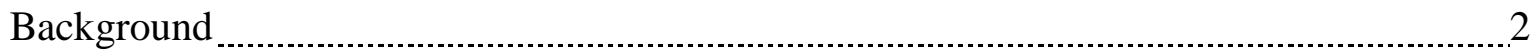

Methodology

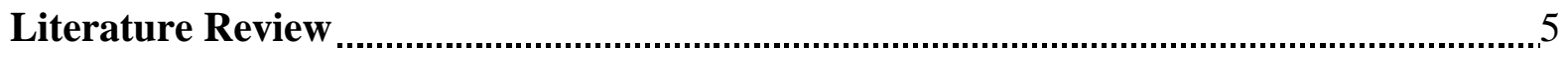

Benefits

Public Perception

Technology

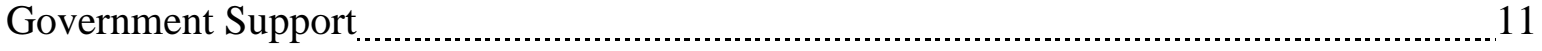

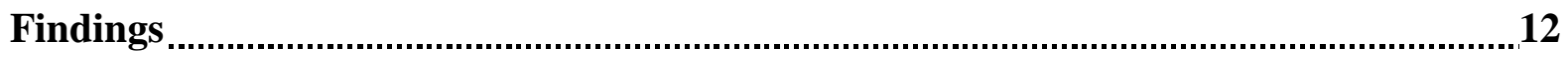

Governing Tree Commission or Advisory Board $\ldots 13$

Tree Inventory Elements $\ldots \ldots \ldots$

Funding

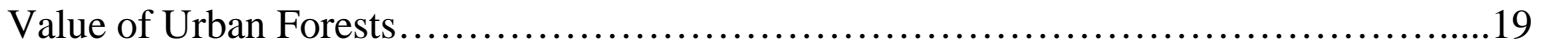

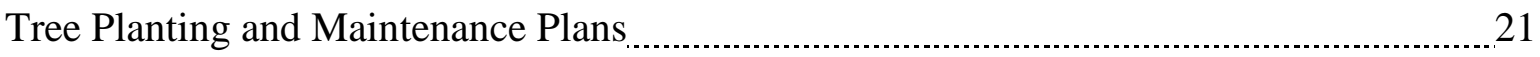

Tree Risk Reduction Plan/Emergency Storm Response $\ldots$

Public Relations, Education, and Community Involvement _......................................24

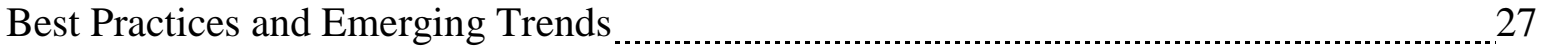

Best Practices Scoring

Analysis and Conclusion ................................................................................................. 34

Identifying the Extensiveness of the Urban Forest Management Plans _........................... 34

Main Findings and Recommendations _................................................................... 38

Implications for Urban Forestry Management in Santa Clara County _..................................

References 


\section{$\underline{\text { List of Tables }}$}

Table 1: Inventory of Trees, Species, Size Mapping/Location Software...................15

Table 2: Forestry Budgets and Per Capita Funding..................................17

Table 3: Trees Trimmed.......................................................19

Table 4: Total Canopy Coverage Data Analysis and Ecological Values....................20

Table 5: Tree Planting and Maintenance Plans....................................22

Table 6: Tree Emergency Storm Response Plans..................................24

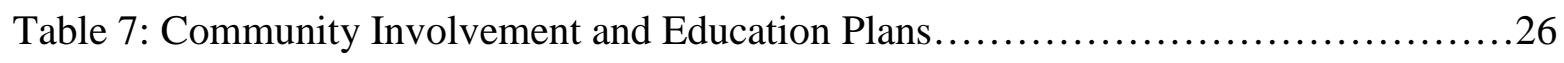

Table 8: Best Practices and Emerging Technologies................................27

Table 9: Best Urban Forest Management Practices Scoring............................30 


\section{INTRODUCTION}

\section{Declaration of Intent}

As urban populations increase and space is at a premium in cities, urban forests and the ecological benefits they provide are becoming more valuable. They are valued for their aesthetic benefits as well as their environmental benefits. These benefits are increasingly being monetized to support their management and to increase their value over time. Santa Clara County lies in the heart of Silicon Valley, the high technology capital of the country.

The first step in this study was to determine whether cities in the county had an UFMP, and if not, what type of system they use for managing their trees. Less developed programs may manage their trees via municipal tree ordinances, which are local laws used to maintain and protect trees. They may also contain provisions for planting, maintenance, and removal of street trees within public right of ways. Community forests are a further developed form of tree management in which the local community is directly engaged in tree management and land use decisions. This is a more collaborative type of management and involves numerous partners, including community, government, and non-government or nonprofit organizations (Little, 2012). The more mature management systems will employ an urban forest management program (UFMP), defined by the American Public Works Association as “an action plan; it gives the public work agencies detailed information, recommendations and resources needed to effectively and proactively manage public trees” (American Public Works Association, 2015, p. 1).

This study benchmarks the three Santa Clara County (SCC) cities that have formally developed UFMPs against the Urban Forestry Best Management Practices for Public Works 
Managers outlined by the American Public Works Association. (American Public Works Association, 2015). These components include the following:

1. governing tree commission or advisory board;

2. inventory of trees/species/size/mapping location software;

3. budget/benefit analysis

4. $\quad$ canopy coverage/ecological values;

5. tree planting and maintenance plans;

6. $\quad$ tree emergency storm response plan; and

7. public relations and education plans

\section{Background}

The three cities evaluated in this study are Mountain View, Palo Alto, and Sunnyvale. They are contiguous to one another in the northwest section of Santa Clara County (SCC) and are approximately 32 miles south of San Francisco. Each city was provided funding through the California Department of Forestry and Fire Protection’s (CALFIRE) Urban and Community Forestry Program to produce its UFMP. Because they took the next step, going from a municipal tree management system to an urban forest management plan with a strategic management plan to increase the urban forests' value over time, these cities form a basis for understanding best practices in urban forestry that could be emulated by others.

An UFMP established on current tree inventory data and examination of available budget resources, staff, and equipment is a crucial tool for protecting urban forests. The UFMP is a plan of action that provides public works agencies with comprehensive information, advice, and resources 
to successfully and proactively administer the management of a municipality’s tree infrastructure (American Public Works Association, 2015). This research will provide the cities of SCC with practical information on establishing or improving an UFMP.

This research uses publicly available information to compare the individual program components, criteria, and performance indicators and compare the differences, with the goal of highlighting best practices. The study examines the following elements:

a) whether the three cities have complete urban forest management plan components;

b) whether the three cities perform the management processes very well and have process practices that are adaptable to other cities; and

c) what these three cities show about the emerging trends are in urban forest management, and who is following them.

\section{METHODOLOGY}

This section presents the method for investigating the research objectives described in the introduction. The primary objective of this study was to methodically compare municipal urban forest plans in three SCC cities that had made the effort to produce an UFMP. Urban forest management plan development should be comprehensive to account for the stage of current development and the range of diversity of the forest, the tree-related services provided and the management of tree-related issues, such a utility lines. After acquiring each city’s UFMP, each plan was analyzed for comprehensiveness based on evaluative criteria published by the American Public Works Association (2015) and the United States Department of Agriculture, Forest Service Southern Research Station Urban Forest Sustainability and Management Audit System (2015). 
This research analyzes the major components of the plans to be measured, the completeness of the measuring criteria, and develops a scoring calculation based on the depth of comprehensiveness.

In this study, the benchmarking method was selected because of its ability to identify, compare, and reveal exceptional practices from other organizations that are considered the highest current standards in the industry (Mathison, 2005). Benchmarking is usually thought of in terms of corporations or businesses, and became a valuable management tool in the late 1980s when Xerox initiated the process. In this study, benchmarking will compare one city's UFMP processes and performance to best practices from the industry and the entire urban forest management trade (Blackman, 2002).

Before researching the city's UFMP, an application was submitted to Institutional Research Board at San Jose State University to obtain an exemption, since the subject of the benchmarking is a public agency program that generates public information.

Each city's UFMP is ongoing and proceeding at different stages of management, and some cities' goals are more self-evident than others. The issues for each city’s UFMP are multiple, including funding, age of program, community involvement, number of staff, whether they provide services to a city's utility department, and even geographic location as it pertains to soil, rainfall, sunlight, and variability of weather. In the field of urban forestry, the amount of canopy cover or of crown and leaf structure is an effective measure of the health of an urban forest (Clark, Matheny, Cross \& Wake, 1997). However, other criteria and performance measures determine the interrelationship of the assorted program goals with the program functions. As an example, examining, the periodic function of tree trimming, with the overall goal of tree maintenance has been measured. 
The goal of this analysis was to determine if the UFMPs in these three cities are in line with the recommendations of the APWA (2015) and United States Department of Agriculture (USDA), Forest Service Southern Research Station (2015), to what degree the three cities’ UFMPs fall below the standard in each area, and what the best features of each UFMP are. Each city was assessed according to the presence and thoroughness of the plan features recognized by the American Public Works Association. (2015).

\section{LITERATURE REVIEW}

\section{Benefits}

In a city, the term "urban forest" refers to all privately and publicly owned trees in an urban area, including parks, backyards, streets, and natural spaces. Urban forests are an intrinsic part of community ecosystems that act together to appreciably affect the quality of city living (Nowak, 2010). Urban forests provide numerous benefits to the environment. The largest is that trees produce oxygen through the process of photosynthesis. A United States (U.S.) Forest Service report found that a 30-foot tree could produce as much as 260 pounds of oxygen annually, and that a person typically consumes 386 pounds of oxygen in a year. Therefore, two-medium sized trees can supply all the oxygen one person needs annually (McPherson, 2007).

Trees manage storm water runoff by absorbing rainwater through their roots and leaves, protecting soil from erosion and soaking up pollutants and keeping them out of waterways while recharging the groundwater supply. Trees can help reduce energy demand up to 30\% by shading homes in the summer. They can reduce heating bills by $2 \%$ to $8 \%$ when planted accurately to reduce wind exposure (Simpson, 1996). 
In addition, urban forests can help alleviate climate change through carbon sequestration, a process of taking carbon out of the atmosphere and lessening the greenhouse gas effect. One study calculated that urban trees in the continental U.S. store 770 million tons of carbon valued at $\$ 14.3$ billion (Nowak, 2002). Trees can also remove gaseous air pollution through uptake by the leaf stomata. Trees do this by diffusing the gas into intercellular spaces in the leaf and then absorbing it via a water layer that forms acids or otherwise reacts with the inner leaf cells (Nowak, 2006).

In addition, there is a direct economic benefit to the value of real estate. Consumers often shop longer and are willing to pay more for parking in downtown business districts that have large well-maintained trees (Wolf, 1999). Indeed, it has been said that homes with trees are worth more. The American Nursery and Landscape Association reported that a large tree canopy can add 2\% to $9 \%$ to the value of a home (Stigarll, 2009). Furthermore, property values are greater in communities with neighborhood parks. A university professor from Texas A\&M who researches parks and recreation found that in 20 out of 25 studies, for residences near parks and open space, trees contributed to higher property values (Crompton, 2000). Residential street trees escalate the worth of adjacent properties. Donovan and Butry (2010) calculated that street trees in front of homes added $\$ 8,870$ to the market price, or $3.4 \%$ to the median property value of $\$ 259,000$ in Portland, Oregon. Their research results were based on actual market prices and the investigators used multiple regression modeling that controlled for a range of tree factors, household variables and neighborhood characteristics. Homes with residential street trees also sold quicker, with the average time on the real estate market shortened by 1.7 days. They calculated that street trees provided \$1.35 billion to home values in Portland, totaling \$15.3 million annually in tax revenue (Donovan \& Butry, 2010). 
These examples show that urban forests offer numerous benefits for society, and it is important that they should be strategically managed. In their study of the variations in municipal urban forestry policies in Canada, Conway and Urbani (2007) found that tree policies differed greatly across the Toronto metropolitan area, directly corresponding to the characteristics of the region's urban forests. Communities with more support for urban forest management had more canopy than communities with little of no municipal tree ordinance support. Their results emphasized the need to help smaller municipalities develop urban forestry policies (Conway, 2007).

\section{Public Perception}

Arborists have recognized that the public's perception of the urban forest changes over time. In their report on the state of urban and community forestry in California, which followed trends since 1988, Thompson and Ahern (2000) found that environmental benefits like improved wildlife habitat and soil retention were rated as fairly unimportant benefits in the past, but recently, they have grown in importance. Another change in attitudes as well as management practices is the amount of green waste from tree trimming and removals that is being re-used. They found that approximately $20 \%$ of cities are now using these materials for mulch and energy instead of depositing them in landfills. More recently, the phrase, urban forestry has expanded into a term called "green space”. Green space is described as being associated with open space, and is land that is partly or completely covered with grass, trees, shrubs and other vegetation and includes parks, community gardens and cemeteries (Maas, Verheij, Groenewegen, De Vries \& Spreeuwenberg, 2006). In his paper, Urban Green Spaces and an Integrative Approach to Sustainable Environment, Haq (2011), describes the important roles played by green spaces as being social, economic, cultural and environmental. He suggests that people satisfy most of their leisure needs 
within the locality of where they live, and that green spaces within urban areas provide a sustainable amount of the total outdoor recreational opportunities. Viewed from this point, urban forests are recognized as providing social and psychological benefits. His research found that people, who were exposed to the natural environment, had decreased stress levels as compared to those who lived in a city environment. In the same research, patients in a hospital whose rooms were facing green spaces had a 10\% faster recovery rate and needed 50\% less pain relieving medication as contrasted with patients who had rooms facing a constructed wall (Haq, 2011). Indeed, it can be suggested that the presence of urban forests can sooth the negative health impacts of stressful life events. In their program, Urban Connections and Social Dynamics Program Charter, the U.S. Forest Service, Pacific Southwest Research Station (2011), charted a program with the "purpose to understand and enhance the interconnections among ecosystems, people and societies in order to inform policy and improve management of forests and other natural resources" (p. 3). This furthers the perception that urban forests are valued for their public health and social benefits.

Community support for UFMP is characterized by a tree commission, celebration of Arbor Day, and tree plantings. This is important insofar as how the public takes part in tree-related activities and generates community support. In her report on the Los Angles Million Tree Initiative, Pincetl (2010) found that implementing the program was more complicated than expected. Coordination of effort among nonprofits, residents, and city administration was essential to the program's success and was achieved through a partnership approach (Pimcetl, 2010). In a report from the state of Utah, researchers found that many communities were willing to accept assistance from public agencies, nonprofits, and other groups. They found that the smallest 
communities had the most inadequately developed programs and that they may not have the ability to take advantage of more highly technical support, while few large cities need much support at all. The researchers found that the best way to influence a large population was to spend effort on increasing activity in midsized communities up to 50,000 people. This could help establish a tree commission or a simple ordinance. More technical project grants could be directed to larger towns (Kuhns, Lee, \& Reiter, 2005).

\section{Technology}

The most impressive development in UFMP is the progress in technology, which has led to advancement in the scientific tools used in measuring the urban forest. In 2002 a group of software programs called i-Tree was developed by the U.S. Forest Service. It enables the use of a handheld device to remotely gather data that measure urban forest ecosystem values, including carbon storage, storm water runoff, and pollution removal (U.S. Forest Service, 2015). In addition, the tree carbon calculator, developed by the Urban Forest Research Center, measures reduction in energy use for cooling and heating, annual sequestration of carbon dioxide, and total carbon stored by trees (Vargas, 2011) .

Probably the most effective in garnering support for urban forest programs is the California Cap-and-Trade program, through which the Air Resources Board developed a compliance offset program in which greenhouse gas (GHG) emission reduction or sequestered carbon generates California Air Resources Board (CARB) offset credits. Forests and urban forests are one of the tools that can be used for offsetting greenhouse gases. Qualified urban forest projects can earn carbon credits that they can then sell to businesses emitting more than their allowed amounts of GHGs (Housholder, 2013). The California Climate Action Reserve is the agency in charge of 
establishing protocols and maintaining the Climate Registry, a nonprofit GHG emissions registry for North America. The registry provides the tools and resources to help organizations calculate, verify report, and administer their GHG emissions in an openly transparent manner (Climate Registry, 2016).

To date, there has only been one city in the State of California to engage in this program, as part of a city's urban forestry program. The City of Santa Monica, California, GHG tree planting project was designed to plant 1,000 new trees in parkways along the boulevards of the city. The main objective was to measure the removal and consequent storage of C02 from the atmosphere. The Climate Action Reserve necessitates strict regulations for the project, requiring trees to be planted 16 feet apart and mapping the location of each tree to demonstrate it is a new site. But what is probably the biggest over-all hindrance to the project it that the project owner must record growth of each tree over the next 100 years and report the results to the registry. Many cities are hesitant to commit to a program over such a long span of time (Little, 2012). In speaking with, Walt Passmore, Urban Forester for the City of Palo Alto, he replied that the city was not ready for this program yet, but that it would be considered in the next 10-15 years (W. Passmore, personal communication, December 9, 2015). Neither the City of Mountain View, nor the City of Sunnyvale suggested that they were currently interested in the cap and trade program in their UFMP's. Of the approximately 87+ projects listed in the State of California at the time of this research, most were developed by large timber companies such as Sierra Pacific Industries or Mendocino Redwood Company, although the City of Arcata has a project registered. The project has a history of intensive harvest management which they intend to restore and provide connectivity with the city's existing community forests (Climate Action Reserve, 2016). 


\section{Government Support}

The California Department of Forestry and Fire Protection (CAL FIRE) is the lead government organization supporting urban and community forestry programs. It is authorized under the Urban Forestry Act (PRC 4799.06-4799.12) to advance management of trees in communities in the state. Grant funds were made available in the 2014/2015 fiscal years from the California Greenhouse Gas Reduction Fund and the USDA Forest Service Urban and Community Forestry Program Fund. This grant program funds advancement and execution of urban forest management actions to decrease GHG emissions by the local community to enhance the benefits of their local urban forests. The grants were allocated for tree inventories and establishing new management plans or updating existing ones, with the expectation that the project would lead to sequestration of considerable amounts of GHGs. To qualify for the grant, communities had to match $25 \%$ of the funds with in-kind activities or materials related to the project. CAL FIRE Urban \& Community Forestry provided the other $75 \%$ of the cost for the projects (CAL FIRE, 2014). The cities researched in this study were the only cities in SCC that qualified for the grant money for these years.

CAL FIRE collaborates with many other organizations, including California Releaf, a nonprofit association that works statewide to encourage alliances between area groups, the United States Forest Service (USFS) Pacific Southwest Research Station, Center for Urban Forest Research, which conducts ecological and social science research, the Urban Forest Ecosystem Institute at the California Polytechnic State University in San Luis Obispo, which performs education and research, and the California Urban Forests Council (CaUFC). CaUFC began in 1968 as the first urban forest council in the country. The council consists of tree professionals in association with cities, public works, landscape architects, arborists, and the nursery industry to support seven 
regional councils throughout California. CaUFC’s main purpose is to coordinate workshops, administer a certified urban forestry program and manage the Invest from the Ground Up program (IFGU). IFGU is an online program that presents step by step instructions on how to develop an UFMP. Its main goal is to help communities realize that the investment they put into growing and maintaining urban forests provides multiple returns on their efforts (CaUFC, 2015).

In all locales, education is the largest element in improving management of urban forests. Greater emphasis needs to be put on exchange of knowledge and development of ideas through communication with city administrators, city foresters, arborists, nonprofits, civic organizations, and citizens (McPherson, 2000).

\section{FINDINGS}

The findings are based on benchmarking the major components of each city's UFMP and whether each addresses the six basic components of an UFMP, including an advisory committee or tree board, tree inventory and mapping program, urban forest cost/benefit analysis, tree planting and maintenance plans, tree emergency response plan, and public relations and education plans (American Public Works Association, 2015). These components were further evaluated as to the extent that they were achieved and were graded on an overall scale. This scale was derived from the United States Department of Agriculture (USDA) Forest Service Southern Research Station Sustainability and Management Audit System Checklist Process and includes the following values.

\section{Evaluation}

0) Not Practiced

1) In Development

2) Adopted Common Practice

3) Exceeds Common Practice 
A final matrix was used to benchmark and compute scores, revealing which cites are stronger or weaker in each UFMP component (U.S. Forest Service, 2015).

The National Arbor Day Foundation (NADF) is the largest nonprofit tree-centric organization with the purpose of planting trees and teaching forest conservation. Founded in 1972, it developed the Tree City USA program, which provides a method for communities to take care of and develop their public trees. A community can achieve Tree City USA status by completing four core standards of urban forestry management. These are

1) Maintain a tree board or department;

2) Establish a community/city tree ordinance;

3) Spend at least $\$ 2$ per capita on urban forestry; and

4) Celebrate Arbor Day.

Each of these three cities is identified as a Tree City USA approved city on the Arbor Day Foundation website, and each received funding from CAL FIRE to prepare an urban forest management plan (Arbor Day Foundation, 2016).

\section{Governing Tree Commission or Advisory Board}

All three cities in this study have been accepted into the Tree City USA program by meeting the four core standards listed above.

1) Tree City USA—14 years; City of Mountain Community Tree Master Plan, adopted September 15, 2015 (City of Mountain View, 2015).

2) Tree City USA —28 years;, Palo Alto Urban Forest Master Plan, adopted May 11, 2015. (City of Palo Alto, 2015). 
3) Tree City USA —-25 years; City of Sunnyvale Urban Forest Management Plan, adopted September 16, 2014 (Bernhardt, Swiecki, Dunn \& Works, 2013).

In addition, all three cities have newly implemented urban forest management plans. All benchmarking data in this study were taken from the cities' urban forest management plans, available to the public on the internet.

The number of years of participation in the Tree City USA program is an indicator of how far evolved each city's UFMP plan is because of the amount of time they have already spent managing their trees. These three cities have been managing their trees for an average of 22.3 years (std. dev. 6.01 years).

\section{Tree Inventory Data Elements}

Tree inventories are a method of determining the number, size, species and health of an urban forest. Technological advances in measurement tools have made the task easier and more efficient, especially by using geographic information systems (GIS) to accurately map each tree's location. Handheld devices that can be used in the field and then uploaded to a software program are typically used for larger inventories. One of the most widely used inventory systems was developed by the USDA Forest Service. Initially released in 2006, i-Tree is a peer-reviewed collection of software free to the public that quantifies the monetary, environmental, and aesthetic benefits of an urban forest. Benefits can be calculated using a complete register or sample data combined with the software tool.

Several different analysis tools can be used for different criteria, including i-Tree Streets, iTree Design, i-Tree Canopy, i-Tree Eco, i-Tree Vue, and i-Tree Landscape (U.S. Forest Service, 2015). The i-Tree Streets software uses tree inventory data to quantify the monetary value of 
annual benefits, including energy conservation, air quality, CO2 reduction, storm water runoff, and aesthetic benefits. Table 1 indicates that the i-Tree streets program in conjunction with aerial imagery was used by all three cities to diagnosis the structure, benefits, and value of their forests. There are many different species of trees in each city, with a statistical variance of 23.57 trees species between each of the cities. Tree species diversity is very important because certain pest populations can decimate a city's trees if there are too many of one species. As an example, Dutch Elm disease, a fungal disease, has annihilated native populations of elm trees on the eastern side of the U.S. Therefore, it is important to plant trees of different species that have natural immunity to certain pests (Denig, 2014).

In addition to street trees, each city has at least a partial inventory of park, landscaped areas, or other trees.

Table 1. Inventory of Trees, Species, Size Mapping/Location Software

\begin{tabular}{|c|c|c|c|c|c|c|}
\hline$\sum_{0}^{2}$ & 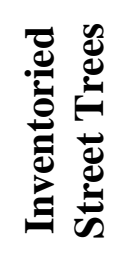 & 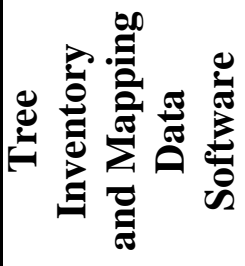 & 兰 & 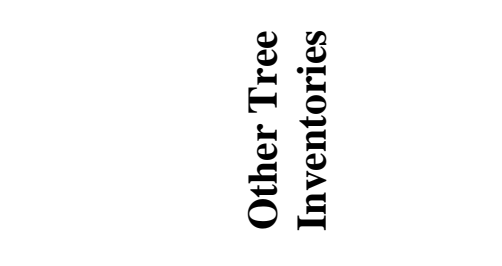 & 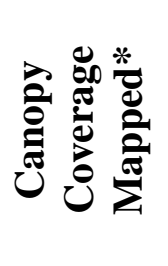 & " \\
\hline Mountain View $^{1}$ & $100 \%$ & $\begin{array}{c}\text { i-Tree Streets, } \\
\text { i-Tree } \\
\text { Canopy } \\
\end{array}$ & Yes & $\begin{array}{l}\text { Inventory of park trees and } \\
\text { trees around city facilities }\end{array}$ & Yes $^{1}$ & 230 \\
\hline Palo Alto ${ }^{2}$ & $100 \%$ & $\begin{array}{c}\text { i-Tree Streets, } \\
\text { i-Tree eco }\end{array}$ & Yes & $\begin{array}{l}\text { Summary inventory of park } \\
\text { trees. Mapped heritage trees, } \\
\text { landscape, utility, and } \\
\text { multifamily dwellings. }\end{array}$ & Yes $^{2}$ & 230 \\
\hline Sunnyvale $^{3}$ & $100 \%$ & $\begin{array}{l}\text { TreeKeeper } \\
\text { i-Tree Streets, } \\
\text { Arbor Access }\end{array}$ & No & $\begin{array}{l}\text { Summary inventory of park } \\
\text { trees. Mapped heritage trees, } \\
\text { landscape, utility, and } \\
\text { multifamily dwellings. }\end{array}$ & $\mathrm{Yes}^{3}$ & 190 \\
\hline
\end{tabular}

1 (City of Mountain View, 2015 p. 11.)

2 (City of Palo Alto, 2015 p. 39.)

3 (Bernhardt, 2014 p.47.) 
None of the municipalities has been able to inventory all private trees, but this is not necessary to calculate urban forest value. Canopy coverage is the amount of ground that has tree cover directly overhead, and it is most commonly determined from aerial imagery. It is concerned with both tree density and the canopy spread of individual trees (U.S. Forest Service, 2015). There are different methods of calculating canopy coverage; one is by using Light Detection and Ranging (LiDAR) data by flying overhead (satellite or aircraft) and mapping the physical features of an area in very high resolution (National Oceanic and Atmospheric Administration, 2015). The other method involves collecting field data on tree species' structure and physical characteristics and inputting this data into specialized software such as i-Street Trees and i-Tree Canopy to calculate overall canopy coverage and benefits. In addition, the use of GIS data and random dot grids can also calculate these benefits, as was the procedure that the City of Sunnyvale performed. Calculating canopy coverage is important because it serves as a gauge of the extent to which trees provide ecological values to an area for both public and private trees. The major ecological benefits derived from canopy coverage are carbon sequestration, storm-water runoff reduction, energy reduction, and property value increases (Nowak, 2010).

\section{Funding}

Most cities use their general operating fund as the sole source that supports the urban forest management services, and also includes other services provided by the city including, police, fire, parks, recreation, library planning and public works as well a most administration (Gulick, 2015). Each of the cities identified in this study used their city's general fund, for supporting their UFMP programs (City of Mountain View, 2014) (City of Palo Alto, 2015) (Bernhardt, 2014). 
Urban forests must compete with other city services such as police and fire departments and road and sewer repairs for funding. According to the American Public Works Association, trees are often the first budget item to be cut in times of financial certainty, because they are viewed as a nonessential service. They point out that insufficient funding is one of the leading challenges currently facing urban forests. (American Public Works, Budget, 2015). Funding for urban forests entails many different factors because each forest is in a different stage of development and requires varying levels of care. The budget should provide enough resources to perform preventative maintenance, tree planting and removal, and emergency response, and to maintain staff, equipment, and contractor assistance. The NADF requires that a forestry budget consist of $\$ 2$ per capita to qualify for the Tree City USA program, but a more accepted average is $\$ 5$ per capita (American Public Works, Budget, 2015). Table \#2, indicates the per capita spending for the three cities in this study, indicating that each city far exceeds the nationally required funding for maintaining an urban forest. It also reveals that the city with the least amount of population has the largest per capita and per tree budget. Alternatively, the city of Sunnyvale with the largest population and the largest number of trees had the smallest per tree funding and per capita budget. 
Table 2. Forestry budgets and per capita funding.

\begin{tabular}{|c|c|c|c|c|c|c|c|}
\hline City & $\begin{array}{c}\text { FY 2014-15 } \\
\text { General } \\
\text { Operating } \\
\text { Fund } \\
\end{array}$ & $\begin{array}{c}\text { FY 2014-15 } \\
\text { Forestry Budget }\end{array}$ & $\begin{array}{c}\text { Forestry } \\
\text { Budget as } \\
\text { a\% of } \\
\text { General } \\
\text { Operating } \\
\text { Fund } \\
\end{array}$ & \# of Trees & $\begin{array}{l}\text { Funding } \\
\text { per Tree }\end{array}$ & $\begin{array}{c}\text { Population } \\
2015 \\
\end{array}$ & $\begin{array}{c}\text { Per } \\
\text { Capita } \\
\text { Budget }\end{array}$ \\
\hline Mountain View & $\$ 100.0 \mathrm{M} \mathrm{a}$ & $\$ 1,500,000 \quad \mathrm{~d}$ & $1.50 \%$ & $26,166 *$ & $\$ 57.32$ & $79,378 \quad 1$ & $\$ 18.89$ \\
\hline Palo Alto & $\$ 171.1 \mathrm{M} \mathrm{b}$ & $\$ 2,526,492$ e & $1.48 \%$ & $35,390 * *$ & $\$ 71.38$ & $66,955 \quad 2$ & $\$ 37.73$ \\
\hline Sunnyvale & $\$ 234.7 \mathrm{M} \mathrm{c}$ & $\$ 1,894,268$ f & $0.81 \%$ & $37,000 * * *$ & $\$ 51.19$ & $149,980 \quad 3$ & $\$ 12.63$ \\
\hline
\end{tabular}

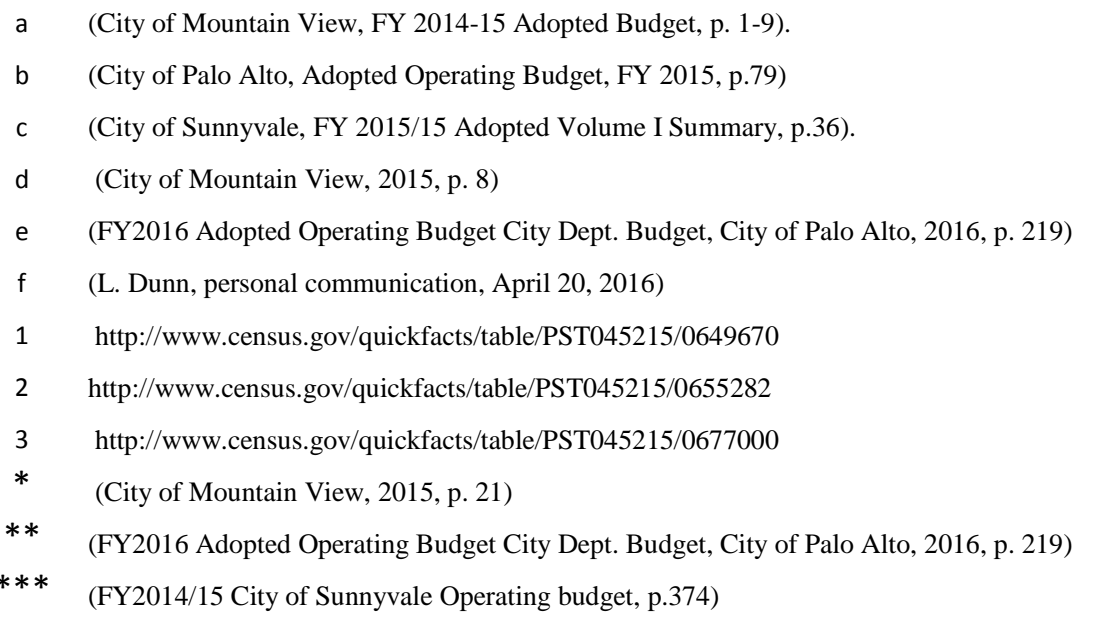

Funding per tree should be considered an indicator and not a comprehensive measure of comparison between cities. In this study, for example, the city of Palo Alto has a fairly unique status, insofar as the city is the provider of their own utilities so utility staff have a rooted interest in how line clearing for trees is performed and consequently might provide more funding for this effort than a private utility provider (City of Palo Alto, 2015).

Typically, throughout the county, urban forest budgets are designated mainly for maintenance (58 percent), then by planting (14 percent) and then followed by management administration (8 percent) (American Public Works, Budget, 2015).

Commonly, tasks that reduce a city’s liability and increase community safety, for instance, pruning and removal have the greatest priority and are performed earliest. Imminent safety hazards 
should always be top priority. However, regular and preventative maintenance should also be an important component of the overall program and budget. Planting should be an important percentage of the overall budget, subsequent only to maintenance and usually does not surpass $50 \%$ of the operating budget (American Public Works, Budgeting, 2015). Table 3 indicates the number of trees trimmed out of the total number of trees in each city for FY2014. It reveals a very comparable trimming maintenance percentage for each city. If tree trimming is a function of a tree maintenance program, then the three cities in this study display highly correlated maintenance functions.

Table 3, FY 2014 Number of Trees Trimmed

\begin{tabular}{|l|c|c|c|}
\hline & $\begin{array}{c}\text { FY2014 \# Trees } \\
\text { Trimmed }\end{array}$ & $\begin{array}{c}\text { FY 2014 Total \# } \\
\text { of Trees }\end{array}$ & $\begin{array}{c}\text { \% of Total } \\
\text { Trees Trimmed }\end{array}$ \\
\hline Mountain View & 5055 a & 35,386 & $14.30 \%$ \\
\hline Palo Alto & 3749 b & 26,166 & $14.30 \%$ \\
\hline Sunnyvale & 5286 c & 37,000 & $14.20 \%$ \\
\hline
\end{tabular}

(City of Mountain View, FY 2014-15 Adopted Budget, p. 4-122).

( FY2014,Adopted Budget, City of Palo Alto, 2016, p. 412)

(FY2014/15 City of Sunnyvale Operating budget, p.219)

\section{Value of Urban Forests}

Using the canopy data analysis, a UFMP can evaluate and calculate the functions of urban forest benefits and place a monetary value on the annual environmental benefits they present. However, managing the forest resource also has costs. Public funds are allocated for planting, pruning, inspection, removal, emergency work, and running the program. An UFMP that includes a cost-benefit analysis can help an urban forest manager estimate the cost of maintaining trees, 
develop an annual budget, validate funding and carry out strategic planning. In addition, when the public can see the value that trees contribute to the health of a city, the forest secures public support (McPherson et al., 2007).

Table 4. Total Canopy Coverage, Data Analysis and Ecological Values

\begin{tabular}{|c|c|c|c|c|c|c|c|c|c|}
\hline$\stackrel{3}{0}$ & 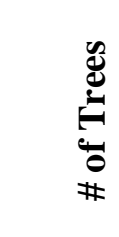 & 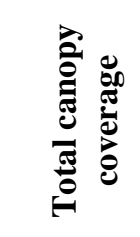 & 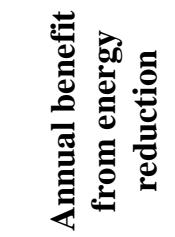 & 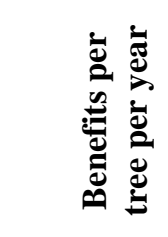 & 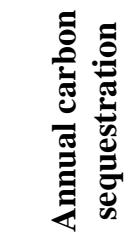 & 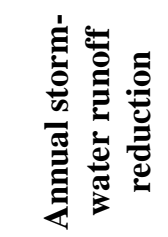 & 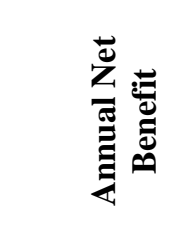 & 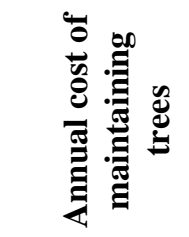 & 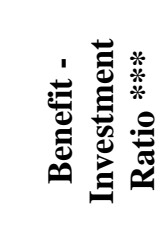 \\
\hline Mountain View 1 & 26,166 & $17.70 \%$ & $\$ 431,062$ & $\$ 305$ & $\$ 35,535$ & $\$ 157,985$ & $\$ 6,500,000$ & $\$ 1,500,000$ & $\$ 5.43: 1 *$ \\
\hline Palo Alto 2 & 29,151 & $37.60 \%$ & $\$ 589,805$ & $\$ 228$ & $\$ 51,563$ & $\$ 170,504$ & $\$ 6,638,513$ & $\$ 2,064,000$ & $\$ 3.22: 1 * *$ \\
\hline Sunnyvale 3 & 37,000 & $18.00 \%$ & Not given & Not given & $\begin{array}{l}\text { Not } \\
\text { given }\end{array}$ & Not given & $\$ 1,079,336$ & Not given & $\begin{array}{c}* * * \text { Not } \\
\text { calculated }\end{array}$ \\
\hline
\end{tabular}

1 (City of Mountain View, 2015) *p. 15

2 (City of Palo Alto, 2015)**p. 44

3 (Bernhardt, 2014) ***

The reason for calculating the annual benefits of street trees in dollars is to compare that amount to the annual cost of maintaining the urban forest and in doing so establish the benefitinvestment ratio (BIR) (U.S. Forest Service, i-Tree, 2015). The City of Mountain View UFMP data, details that the annual value of the street tree benefits is $\$ 6,500.000$ and that the annual cost of maintaining the trees is $\$ 1,500,000$. The i-tree analysis indicates that the BIR is $5: 43: 1$. That is for every dollar that the city spends on street trees, the City of Mountain View collects $\$ 5.43$ in benefits (City of Mountain View, 2015). The same ratio applies to the City of Palo Alto, with every 
\$1 that the city spends on trees; the city reaps \$3.22 in benefits (City of Palo Alto, 2015).

Sunnyvale did list an annual maintenance cost in their UFMP.

The data in Table 3, for ecological benefits based on canopy coverage were calculated for a different year for each study, with two different contractors, and appears skewed based on the number of trees. Both Palo Alto and Mountain View used i-Street Tree software to calculate their

benefits of canopy coverage. Although Sunnyvale has more canopy coverage (18\%) than Mountain View (17.7\%) their contractor did not run the software to provide the value of the urban forest. However, given that it is slightly higher than Mountain View there should be a similar outcome if data had been run.

Because Sunnyvale's analysis was run by a different contractor the annual net benefit calculation is based on a different algorithm than Mountain View and Palo Alto, and thus is not comparable. This demonstrates the value of using the canopy value calculation for supporting the cost/benefit analysis of an urban forest. This type of cost-benefit analysis can help urban forest managers justify more funding for planning, construction, management, and maintenance. Methodical analysis of urban forest management has been reported in scientific journals and the science has led to increased quality of our community forests (McPherson et al., 2007).

\section{Tree Planting and Maintenance Plans}

One purpose of an UFMP is to manage maintenance requirements for individual trees and to prioritize these tasks. General maintenance includes pruning, fertilization, removal, planting, disease and insect treatment, mulching, watering, and grate repair. Primary tasks involve protecting public safety and are based on the potential risk of tree failure to people, public right of way, and property. In addition, maintenance practices are geared at improving the overall health, vitality, 
and aesthetics of the trees. UFMP's also include planting plans, and use tree inventory data to determine trees species selection and locations. Choosing what species of tree to plant and where to place it are important because of the long-term consequences of these decisions (Thompson, 1994).

Table 4 shows data, taken from each city’s respective UFMP, indicating the number of vacant planting spaces, number of trees planted and removed and the maintenance cycle from their maintenance program.

Table 5. Tree Planting and Maintenance Plans

\begin{tabular}{|c|c|c|c|c|c|}
\hline 胥 & 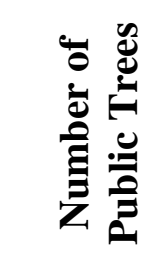 & 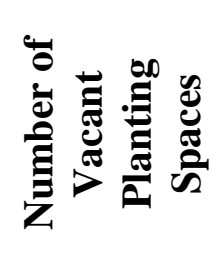 & 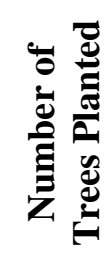 & 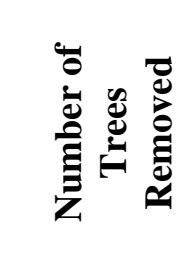 & 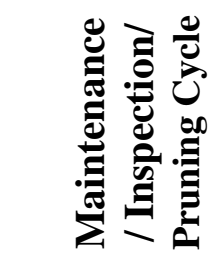 \\
\hline Mountain View & 26,166 & 5,866 & 240 & 239 & 7 years \\
\hline Palo Alto & 33,146 & 2,353 & 150 & Not listed & 7.4 years \\
\hline Sunnyvale & 37,000 & 4,537 & 529 & 470 & 7 years \\
\hline
\end{tabular}

1 (City of Mountain View, 2015)

2 (City of Palo Alto, 2015)

3 (Bernhardt, 2014)

The UFMP examines this data to develop a comprehensive planting plan and focuses on items related to new tree plantings and care. The plan also categorizes the subjects that most need improvement and proposes tree species suitable for the existing planting spaces, conveys detailed maintenance plans for new trees, and gives methodological knowledge regarding tree planting practices. The City of Sunnyvale does a good job of planting more trees than it removes. This will ensure that the city’s canopy will increase significantly. The City of Mountain View has an equal 
number of trees planted and removed and will have a more difficult time growing its overall canopy and increasing its ecological benefits. The City of Palo Alto does not monitor its removals, making it difficult to ensure that an adequate stocking level can be achieved.

\section{Tree Risk Reduction Plan/Emergency Storm Response}

The American Public Works Association’s best management practices prescribes that every UFMP should have a risk reduction and emergency response plan for public works agencies in the event of severe storm emergencies. (American Public Works Association, 2015) When destructive storms such as hurricanes, ice storms, or wind storms strike a city, a large amount of woody debris needs to be collected and disposed of. In addition, there is the threat to safety from hanging tree limbs and overturned trees, which interfere with emergency services by blocking streets, causing power outages, and damaging property. The effect of these incidents can overwhelm municipal services and impede recovery. An emergency UFMP can reduce storm impact through preventative maintenance and methodical risk reduction. The long-term objective is to create a disaster preparedness program that describes policies and procedures that improve the performance and readiness of emergency support operations (American Public Works, 2015).

An UFMP emergency response is certainly a proactive plan to achieve. Geographically, an emergency plan is more pertinent to some parts of the country than to others. In the San Francisco Bay area, storms are typically limited to heavy rain and wind that can uproot trees. In reviewing each city's UMFP, none had a detailed storm emergency plan. However, each did state that the city had emergency response teams available 24 hours per day for every day of the year. as well as contractors on standby that could be called in to help. Listed below is the department in each city that is responsible for emergency services when a storm takes place. Palo Alto had more 
robust details, indicating that it had communications methods in place and staff trained in accordance with the Federal Emergency Act (Incident Command System standards) and the American National Standards Institute (City of Palo Alto, 2015). Line clearing creates a conflict between trees and power lines. However, the City of Palo Alto is the operator of its own electric utility, including poles, transformers and wires. These are also public assets and the city staff and community all, have a vested interest in both sides of this concern. Whereas, the cities of Mountain View and Sunnyvale rely on Pacific Gas and Electric, a publicly traded stock corporation, for preventative tree maintenance and emergency response when power lines are involved.

\section{Table 6. Tree Emergency Storm Response Plan}

\begin{tabular}{|c|c|}
\hline City & Responsible Division \\
\hline Mountain View (2014) & Forestry and Roadway Division, 24/7 \\
\hline Palo Alto (2016) & Public Works Emergency Operations, 24/7 \\
\hline Sunnyvale (2016) & Public Works, Street Tree Services, 24/7 \\
\hline
\end{tabular}

1 (City of Mountain View, 2015)

2 (City of Palo Alto, 2015)

3 (Bernhardt, 2014)

\section{Public Relations, Education, and Community Involvement}

Developing an UFMP is a longstanding obligation involving not only the city's public works department, but also the citizens. Trees are viewed differently by different people and can elicit positive and negative emotional reactions from the public. A critical component in an UFMP is forming a group of local citizens who care about and want to take part in the care and maintenance of the community's trees while working with the city's agency to help it achieve its objectives. The purpose of these citizen advisory boards is to recommend direction or alternatives regarding UFMP 
objectives and to rely on the city's public works agency to carry out the work. In this way, the community can take pride, be involved, and have a stake in the future of the UFMP.

Community involvement is essential to any UFMP. It allows residents to take ownership in the way their city is managed and utilizes the public process to involve community members and incorporate their ideas. A municipality can successfully achieve its goals by educating community members, public officials, and other agencies in the city. An UFMP can recommend workshops, promote media relations, and educate citizens concerning trees and the UFMP. These recommendations may include conducting a public meeting to discuss the community tree inventory and the benefits trees provide, organizing a community tree stewardship organization, and notifying residents of planting activities that will take place each year. In addition, bringing in local experts to speak on tree care and landscaping helps educate and involve local residents in their community (Thompson, 1994).

Table 6, indicates the type of community involvement that each city has developed according to each city's UFMP and whether they currently have an education program. The city of Palo Alto has engaged the nonprofit organization Canopy since 1996 to support its urban forestry programs (City of Palo Alto, 2015). Mountain View Trees is a volunteer nonprofit organization started in 2006 that offers community tree planting events, self-guided tree walks, and online literature on tree care (City of Mountain View, 2015). The City of Sunnyvale developed a volunteer nonprofit organization in 2014 named Sunnyvale Urban Forest Advocates that organizes tree plantings and tree walks and works with residents on tree care on private property (Bernhardt, 2014). 
Table 7. Community Involvement and Education Plans

\begin{tabular}{|c|c|c|}
\hline City & Nonprofit Organization & Education Programs \\
\hline Mountain View (2014) & $\begin{array}{c}\text { Volunteer, Mountain View } \\
\text { Trees, } 2006\end{array}$ & Plantings, tree walks, education. \\
\hline Palo Alto (2016) & Independent, Canopy, 1996 & $\begin{array}{l}\text { Planting, care, education and } \\
\text { outreach, teen foresters, advocacy, } \\
\text { community services. }\end{array}$ \\
\hline Sunnyvale (2016) & $\begin{array}{c}\text { Volunteer, Sunnyvale Urban } \\
\text { Forest Advocates, } 2014\end{array}$ & $\begin{array}{l}\text { Plantings, care, tree walks, } \\
\text { education. }\end{array}$ \\
\hline
\end{tabular}

1 (City of Mountain View, 2015)

2 (City of Palo Alto, 2015)

3 (Bernhardt, 2014)

\section{Best Practices and Emerging Trends}

This research has shown that the amount of canopy coverage provides data to use in calculating the financial benefits of an urban forest. Over the past two decades, naturally forested regions of the country have lost $25 \%$ of their canopy cover, and impermeable surfaces have increased approximately 20\%. These changes have had monetary and ecological impacts on communities' air and water systems. Urban areas can offset the impact of urban development by developing urban forests' natural ability to lessen environmental impacts (US Geological Survey, 2006). For local governmental planners responsible for managing urbanization, the issue is not exclusively getting the city to plant more trees. It is a more multifaceted process involving every aspect of the green infrastructure process. 
Best practices are practices or procedures that are the acceptable or most effective method to reach to a desired result. Best practices in urban forestry involve using sustainable practices while developing and maintaining the forest (Schwab, 2009). Table 7 shows that all three cities have deployed a strategic management plan as part of their UFMP to organize management activities and set up priorities to ensure that they are working toward their established goals.

Table 8. Best Practices and Emerging Technologies

\begin{tabular}{|c|c|c|c|c|c|c|c|c|}
\hline ن & 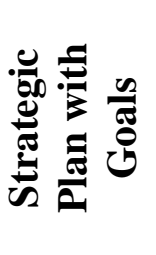 & 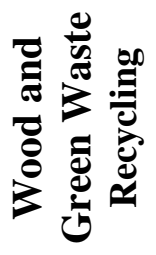 & 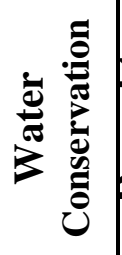 & 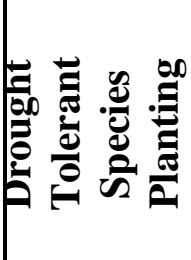 & 造 & 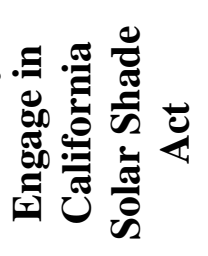 & 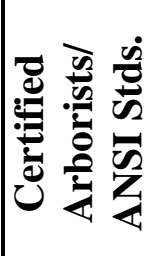 & 密 \\
\hline $\begin{array}{c}\text { Mountain } \\
\text { View }\end{array}$ & $\mathrm{X}$ & $\mathrm{X}$ & $X$ & $\mathrm{X}$ & $X$ & 0 & $\mathrm{X}$ & $X$ \\
\hline Palo Alto & $X$ & $\mathrm{X}$ & $\mathrm{X}$ & $X$ & $X$ & $X$ & $\mathrm{X}$ & $\mathrm{X}$ \\
\hline Sunnyvale & $\mathrm{X}$ & 0 & $X$ & X & $X$ & $X$ & $X$ & $X$ \\
\hline
\end{tabular}

1 (City of Mountain View, 2015)

2 (City of Palo Alto, 2015)

3 (Bernhardt, 2014)

Mountain View and Palo Alto have both initiated a wood and green waste recycling program in which residual parts of removed trees are cut into fine pieces and used as mulch around the base of growing trees to enrich and insulate the soil. Similarly, water conservation is an important part of California's state policies and employs recycled water, drip irrigation, and cultural methods such as mulching to protect tree roots and modify soil temperatures. Additionally, each city plants tree species that are drought tolerant. 
An evolving technology in urban forestry is the use of engineered soil mix, which is designed to be compressed enough to sustain pavement but still allow root growth. These products use structural grids composed of interlocking frames filled with non-compacted soil to grow trees to a larger size. A patented example is Silva Cell technology, a modular hanging pavement technique that uses soil volumes to support large tree development (DeepRoot GreenInfrastructure, 2016). All three cities have some type of concrete or soil program in their UMFP to enhance the growth of newly planted trees. A major complaint of residents is the damage that trees do to their sidewalks that they have to pay to repair. The City of Mountain View acknowledges this as one of its challenges and expresses the need to examine supplementary options for expanding the root zone area beneath pavements, “These options may include pervious pavements, structural soils and suspended sidewalks” (City of Mountain View, 2015, p.36). The City of Palo Alto UFMP, has listed under it Goals, Policies, and Programs, to "explore ways to prevent conflicts between tree roots and underground infrastructure such as requirements that limit the location of underground utilities to a corridor-preferably coincident with the driveway” (City of Palo Alto, 2015, p.144). The City of Sunnyvale has expanded its concrete maintenance division to perform "concrete repair around existing city trees through .....performed by personnel with knowledge of tree physiology and structure. This safeguards the City's investment in street trees”, (Bernhardt, 2014, p.68).

An emerging local government policy issue related to trees is the greater use of residential solar panels and the problem of an existing tree's ability to hamper the collection of solar radiation. The cities of Palo Alto and Sunnyvale have actively recognized and enforced the California Solar Shade Act, which exempts trees that were installed prior to the act and trees that replace previously exempt trees that have died or been removed. The act prohibits a newly planted tree from casting a 
shadow over more than $10 \%$ of a solar panel on an adjacent property between 10 a.m. and 2 p.m. (City of Palo Alto, 2015). Mountain View had not recognized this state act in its UFMP.

All three cities employed certified arborists who have completed a certification process by the International Society of Arboriculture to ensure that they have the proper training to manage trees correctly. Certified arborists are trained in the methods and procedures by the American National Institute of Standards (ANSI) and follow the norms and guidelines that directly impact the management of trees (International Society of Arboriculture, 2016).

Another best practice that each UFMP employed was use of community surveys to understand how its citizens perceive their community forests, what they viewed as important, and what they identified as serious threats to the urban forest. Mountain View engaged citizens through an online survey and a community meeting that included discussion and planning sessions to identify goals and objectives for the UFMP. The survey included 24 questions regarding citizens' views of the benefits of trees, their understanding of urban forestry and heritage trees, and their expectations for tree care and tree preservation. The survey gathered a total of 596 responses, with 493 complete surveys. Eighty-six percent of those surveyed "strongly agreed" that the city of Mountain View's trees are important to the quality of life. Eighty-five percent also "agreed” or "strongly agreed" that Mountain View needs more trees. When asked about the environmental benefits of trees, $46 \%$ identified air quality as the greatest benefit, followed by reduction of outdoor air temperature through shading and decreased energy use (City of Mountain View, 2015).

The City of Palo Alto also performed a citizen's survey and delineated the results on the city's website and the UFMP. The city and its nonprofit, Canopy, led a campaign to promote participation and received more than 600 responses. Ninety seven percent of those surveyed rated providing shade and cooling buildings as the most important benefit of trees. Ninety five percent 
responded that trees were important because they are beautiful, and $87 \%$ responded that trees are important because they reduce air pollution. Palo Alto further refined the survey with a list of "Hot Topics,” open-ended questions including negative impacts from developments and the disparity between the number of trees in north and south Palo Alto (City of Palo Alto, 2015). The City of Sunnyvale did not indicate a citizen survey in its UFMP.

\section{Best Practices Scoring}

To achieve the research objective of tabulating the individual program components, criteria, and performance indicators and comparing the differences, results from the UMFP's analysis were used to assign each plan a comprehensiveness score based on each city's UMFP. Table 8 is a tabulation of scores based on the U. S. Forest Service Sustainability and Management Audit System Checklist Process (U.S. Forest Service, 2015). The scores are an overall assessment of how each city exhibited substantiated evidence of completion in each category. Points were based on the comprehensiveness of the criteria. Each plan was allotted zero points if the practice was not followed or the value was not calculated, one point if the practice was in development, two points if the practice was adopted as a common practice, and three points if it exceeded common practice. A summary of the points scored was calculated along with an overall total percentage points for each plan.

Table 9. Best Urban Forest Management Practices Scoring

\begin{tabular}{|l|c|l|c|c|c|}
\cline { 4 - 5 } & & & \multicolumn{3}{c|}{ Evaluation * } \\
\hline Category & Item & Description & MV & PA & SV \\
\hline & & & & & \\
\hline $\begin{array}{l}\text { Governing Tree } \\
\text { Bommission or Advisory }\end{array}$ & 1.01 & $\begin{array}{l}\text { Tree Board, Commission, or } \\
\text { Advisory Council }\end{array}$ & 2 & 2 & 2 \\
\hline & 1.02 & Ordinance (Public) & 2 & 2 & 2 \\
\hline
\end{tabular}




\begin{tabular}{|c|c|c|c|c|c|}
\hline & 1.03 & $\begin{array}{l}\text { Spends at least } \$ 2 \text { per capita } \\
\text { on urban forestry. }\end{array}$ & 2 & 2 & 2 \\
\hline & 1.04 & Celebrates Arbor Day. & 2 & 2 & 2 \\
\hline \multirow[t]{6}{*}{$\begin{array}{l}\text { Inventory of } \\
\text { Trees/Mapping } \\
\text { Software/Canopy/Species }\end{array}$} & 2.01 & Inventoried street trees & 2 & 2 & 2 \\
\hline & 2.02 & $\begin{array}{l}\text { Tree inventory and mapping } \\
\text { data software }\end{array}$ & 2 & 2 & 2 \\
\hline & 2.03 & Mapped location of trees & 3 & 3 & 2 \\
\hline & 2.04 & $\begin{array}{l}\text { Other (park, landscape) } \\
\text { Inventories }\end{array}$ & 2 & 2 & 2 \\
\hline & 2.05 & Canopy Coverage Mapped & 2 & 2 & 2 \\
\hline & 2.06 & $\begin{array}{l}\text { Number of Different Species } \\
\text { Inventoried }\end{array}$ & 3 & 3 & 3 \\
\hline \multirow[t]{2}{*}{$\begin{array}{l}\text { Budgets/Per Capita } \\
\text { Budget }\end{array}$} & 3.01 & Total Budget & 2 & 3 & 2 \\
\hline & 3.01 & Per Capita Budget & 3 & 3 & 3 \\
\hline \multirow[t]{8}{*}{ Benefits Analysis } & 4.01 & \% Canopy coverage & 3 & 3 & 3 \\
\hline & 4.02 & Annual Net Benefit & 3 & 3 & 1 \\
\hline & 4.03 & Benefits Per Tree Per Year & 2 & 3 & 1 \\
\hline & 4.04 & $\begin{array}{l}\text { Annual Benefit Carbon } \\
\text { Sequestration }\end{array}$ & 1 & 3 & 0 \\
\hline & 4.05 & $\begin{array}{l}\text { Annual Benefit Stormwater } \\
\text { Runoff }\end{array}$ & 2 & 3 & 0 \\
\hline & 4.06 & $\begin{array}{l}\text { Annual Benefit Energy } \\
\text { Reduction }\end{array}$ & 2 & 3 & 0 \\
\hline & 4.07 & $\begin{array}{l}\text { Annual Benefit Property } \\
\text { Value Increase }\end{array}$ & 2 & 3 & 0 \\
\hline & 4.08 & Benefit/Investment Ratio & 2 & 3 & 0 \\
\hline \multirow[t]{5}{*}{$\begin{array}{l}\text { Tree Planting and } \\
\text { Maintenance Plans }\end{array}$} & 5.01 & $\begin{array}{l}\text { Number of Vacant Planting } \\
\text { Spaces }\end{array}$ & 3 & 3 & 3 \\
\hline & 5.02 & Number of Trees Planted & 2 & 3 & 2 \\
\hline & 5.03 & Number of Trees Removed & 2 & 1 & 2 \\
\hline & 5.04 & $\begin{array}{l}\text { Maintenance Inspection } \\
\text { Pruning Cycle }\end{array}$ & 2 & 2 & 2 \\
\hline & 5.05 & $\begin{array}{l}\text { Total Costs Planting, } \\
\text { Removal, Maintenance }\end{array}$ & 2 & 2 & 2 \\
\hline \multirow[t]{2}{*}{$\begin{array}{l}\text { Emergency Storm } \\
\text { Response }\end{array}$} & 6.01 & $\begin{array}{l}\text { Urban Forestry Emergency } \\
\text { Response Plan }\end{array}$ & 1 & 1 & 1 \\
\hline & 6.02 & Response System & 2 & 2 & 2 \\
\hline
\end{tabular}




\begin{tabular}{|c|c|c|c|c|c|}
\hline \multirow[t]{2}{*}{$\begin{array}{l}\text { Community Involvement } \\
\text { and Education Plans }\end{array}$} & 7.01 & Nonprofit Organization & 2 & 3 & 1 \\
\hline & 7.02 & Education Programs & 2 & 2 & 1 \\
\hline \multirow[t]{12}{*}{\begin{tabular}{|l|} 
Best Practices and \\
Emerging Technologies
\end{tabular}} & 8.01 & Strategic Plan with Goals & 3 & 3 & 1 \\
\hline & 8.02 & $\begin{array}{l}\text { Wood and Green Waste } \\
\text { Recycling }\end{array}$ & 2 & 2 & 0 \\
\hline & 8.03 & Water Conservation & 2 & 2 & 2 \\
\hline & 8.04 & $\begin{array}{l}\text { Drought Tolerant Species } \\
\text { Plantings }\end{array}$ & 2 & 2 & 2 \\
\hline & 8.05 & Concrete/Soil Program & 3 & 3 & 3 \\
\hline & 8.06 & California Solar Shade Act & 0 & 3 & 2 \\
\hline & 8.07 & $\begin{array}{l}\text { Certified Arborists/ANSI } \\
\text { Standards }\end{array}$ & 2 & 2 & 2 \\
\hline & 8.08 & Citizen Survey & 3 & 3 & 2 \\
\hline & 8.09 & Carbon Trading & 0 & 0 & 0 \\
\hline & 8.1 & $\begin{array}{l}\text { Tree Plantings in } \\
\text { Economically } \\
\text { Disadvantaged Areas }\end{array}$ & 0 & 1 & 0 \\
\hline & & Total Points & 79 & 92 & 58 \\
\hline & & Total Percentage Points & $67.5 \%$ & $78.6 \%$ & $52.1 \%$ \\
\hline
\end{tabular}

\begin{tabular}{|c|}
\hline $\begin{array}{c}* 0 \text { ) Not Practiced } \\
\text { or not reported }\end{array}$ \\
\hline 1) In \\
Development \\
\hline 2) Adopted \\
Common Practice \\
\hline 3) Exceeds \\
Common Practice \\
\hline
\end{tabular}

The total percentage points scoring outcome of best practices for each individual city’s UFMP does not bring many surprises. As mentioned, the amount of time a city has been working on its urban forest has a lot to do with how comprehensive its initial UFMP will be. Although the City of Palo Alto adopted its UFMP on May 11, 2015, their history of planting street trees dates back to the 1920s with the establishment of a municipal nursery for that purpose. Palo Alto has a 
rich history of tree management and initiated a street tree management plan and task force in 1981. By 1996, it had allotted funds for the nonprofit organization, Canopy, to function as the city’s resource on tree issues and to operate as the city’s liaison for tree planting and tree care events (City of Palo Alto, 2015). It is then not surprising that Palo Alto scored as highest among the three cities. Palo Alto is most progressive with its technical ability to inventory and map each street tree, having performed a detailed canopy analysis. The City of Mountain View, which established its first tree ordinance in 1961, was also able to produce a highly detailed street tree inventory and mapping program (City of Mountain View, 2015). The City of Sunnyvale did not provide tree history in its plan other than to cite its charter for heritage preservation. It did, however, have a detailed inventory, although each tree is not currently mapped using a GIS system (Bernhardt, 2013). It is interesting that each city used the i-Tree software produced by the U.S. Forest to inventory trees and compute ecological benefits. Both Palo Alto and Mountain View used Davey Resource Group, a natural resource and utility consultant service, to assist in developing their UFMP. The City of Sunnyvale used Phytosphere Research, a plant science and research consultant, for the compilation of its UFMP. This is important to note because different consultancies used different calculation methodologies. Sunnyvale’s low score is partially accounted for by the failure to compute a number of values for activities that actually occur, such as carbon sequestration by its 37,000 public trees. 


\section{ANALYSIS AND CONCLUSION}

The analysis discusses the findings and how the results facilitate the overall research goal of increasing knowledge of municipal urban forest management in Santa Clara County. The study revealed diversity and contrasts among the three UFMP in the county, which ranged from a mainly operational plan that did not calculate the range of its ecological values to more comprehensive plans that calculate benefits/investment ratio, along with monetizing the values of the urban forest's ecological benefits. This analysis will address the research objectives by deriving conclusions based on the results from the content analysis and UFMP's best forest management practices analysis. The analysis will then present conclusions on the cities' UFMP's management implications, providing suggestions to improve urban forest management plans in SCC.

\section{Identifying the Extensiveness of the Urban Forest Management Plans}

Using content analysis and the USDA Forest Service Southern Research Station audit criteria, this study benchmarked each city's resources and program capacity to address the first research objective of characterizing the comprehensiveness of the developed urban forest management plans of the three cities in Santa Clara County. The first question was whether these cities' plans address all six components of a sustainable urban forest as defined by the American Public Works Association (2015). This included a governing board, inventory of trees with mapping location software, a budget, definable canopy coverage, benefit and ecological analyses, tree planting and maintenance plans, trees emergency response plan, and a public relations and education plan (American Public Works Association, 2015). The results of this analysis were shown in Table 9 above. 
The second question was addressed by grading the presence or absence of the six components that comprise an UFMP and to what degree the components were thoroughly addressed. The results of this analysis were also shown in Table 9 above.

The next section will discuss the results of the best urban forest management practices (BP) review, providing the basis for recommendations presented at the end of the study.

The first question asked what the components of an urban forest management plan are. These components were outlined by the American Public Works Association in the document titled "Urban Forestry Best Management Practices for Public Works Managers" (American Public Works Association, 2015). It was stated that these are the core components and that plans would vary depending on the age and development of the urban forests. All three cities were members of the Tree City USA program and fulfilled the requirements of the four core standards: maintaining a tree board or commission, having a community tree ordinance, spending at least \$2 per capita on urban forestry, and observing Arbor Day. Qualifying as a Tree City USA indicates that a city is interested in raising public awareness of tree-related issues and educating citizens on the preservation of trees. Tree City USA is a national recognition program that began in 1976 and is sponsored by the Arbor Day Foundation. It is viewed as the first step in the development of a community or urban forest plan (Arbor Day Foundation, 2016). It is therefore not unexpected that the three cities studied in this research were all established Tree City USA participants.

The second component of the plan is an inventory system mapping the species, size, and location within a database with some type of mapping software. It would be difficult to perform a strategic management plan without accurate knowledge of what is being planned. In this instance, the three cities provided an inventory of publicly managed trees, but they varied in their methodology and detail. Both the City of Mountain View and the City of Palo Alto used the U.S. 
Forest Service Assessment tool called i-Tree, which tallies the species and size of an individual tree and calculates ecosystem benefits. These two cites were assisted by the same consulting firm in developing their UFMP and consequently used the same inventory software. The City of Sunnyvale used a different inventory system for its street tree inventory and then further integrated it into another system that their current tree contractor is using. This system lacks the ability to geographically verify tree locations on a map and did not calculate ecological benefits.

Analysis of overall forestry budgets indicate that the city with the smallest population, Palo Alto had the largest budget per capita budget of \$37.73, as compared with the City of Mountain View at $\$ 18.90$ and the City of Sunnyvale at $\$ 12.63$. This trend was also found in a study from the year 2005, in the State of Utah, where public urban forestry expenditures for the smallest communities were $\$ 6.26$ per resident, as compared to $\$ 2.58$ on average for all communities (Kuhns, 2005). Spending per tree was fairly high for the three cities on the whole, as compared to a mean of \$35.64 calculated in a study that the City of Palo Alto included in their UFMP of 24 different cities in various years from 2001 through 2011 (City of Palo Alto, 2015 p.45).

In representing the total canopy coverage data analysis, a similar variability appears. Although Palo Alto has a greater canopy coverage of 37.7\%, the City of Mountain View calculated a great annual net benefit of $\$ 6.5$ million compared to the Palo Alto calculation of $\$ 4.6$ million. There is a difference of six years between when the benefits were calculated, which may account for some of the variability in values. Indeed, when asked about this issue, the City of Palo Alto's Urban Forester replied, "Palo Alto used the i-Tree Streets model to assess the street tree population (only) to calculate monetary benefits, yet calculated canopy cover using a city-wide remote sensing analysis. The benefits calculation could be roughly extrapolated, but compared to Mountain View would require using the same calculation methodologies” (W. Passmore, personal communication, 
February 2, 2016). Palo Alto's across the board benefits were correspondingly lower than those of the City of Mountain View. The City of Sunnyvale, having computed total percentage canopy coverage with an annual net benefit of $\$ 1.1$ million, did not indicate individual benefit amounts. It can be inferred that their inventory system did not allow for this calculation.

Tree planting and maintenance plans were the most similar components among the plans, with a maintenance, inspection, and pruning cycle of seven years. Palo Alto's UFMP was the most detailed, but it did not include a statistic for the number of trees removed. This is an important aspect of analyzing a tree stocking ratio because a plan needs to plant more than it removes to maintain canopy coverage. Palo Alto did note that this was a goal in its strategic management plan. In regard to the next component, tree emergency and response plan, none of the three cities had a valid emergency response plan as described by the American Public Works Association (2015). The association promotes an emergency plan as an addendum to the UFMP to assure service continuity and judicious recovery and restoration (American Public Works Association, 2015). Each of the SCC cities cited a public works division responsible on a 24 hour, seven day a week schedule. Differences in geographical localities may imply a more rigorous emergency plan in different parts of the country.

In fulfillment of the last criteria, public relations and education plans, all three cities had established nonprofit organizations with education programs. It was observed that the ages of these nonprofits varied widely, from originating in 1996 for Palo Alto to a recently formed foundation in 2014 in Sunnyvale. The length of time these nonprofits have been in operation seems to determine how extensive their programs are.

Best practices and emerging technologies were well addressed in each city's plan. All three cities had elements of sustainable urban forest practices, providing multiple systems to conserve 
resources and employ best practices. The components presented by the American Public Works Association were not meant to provide an exact set of requirements for every UFMP, but rather to provide an outline of topics that a comprehensive UFMP should include. The variability between each city's plans and goals illustrates the importance of the point in time when each municipality’s plan is taking place and how it should address its particular needs.

\section{Main Findings and Recommendations}

This section lists the study's five main findings and proposes some targeted recommendations for the cities involved and other municipalities in Santa Clara County that are developing or considering developing an urban forest management plan.

\section{1) Advocate using open access scientific tools that facilitate uniformity in data} collection across communities. Share data collection techniques and "how to's" with other agencies. This will standardize methodologies and improve overall reporting.

Developing comprehensive baseline data on the current state of a city's urban forest is essential in developing an inclusive plan with practical goals and actions that aid in filling management voids. Each municipality has calculated its canopy coverage and ecological benefits using different technological tools. The use of different calculation tools leads to often confusing variances in the overall reporting. Cities should not have to reinvent the wheel each time they collect data. A more rigorous and standardized collection methodology would be worthwhile. 
Recommendation: The U.S. Forest Service, university, and industry partners have developed tools that are available in the public domain. A potential area of research would be an agreed-upon methodology for collection and calculation that could be created as an audit checklist. The resulting product would be a multi-jurisdictional urban forest regional analysis. .

2) All the UFMP have a plan for the cities' publicly owned trees, but few specifically addressed privately owned trees and how to encourage their management and use.

These plans all encourage community engagement through nonprofit organizations that offer outreach in the form of training and education. However, there are no formal plans on how to entice homeowners to plant and care for trees on their own properties. When viewed as a utility, trees reduce home energy use and provide other ecological benefits.

Recommendation:_Cities need to actively encourage homeowners to plant and care for trees. Electrical utility providers should partner with the city in educating the public on the energy conservation benefits of trees. The city should provide tax rebates to residences that specifically plant trees to reduce storm water runoff and the "heat island effect” of sidewalks and roads. In addition, municipal staff should assist residential homeowners in planning where trees would best benefit their property from an ecological standpoint. This would go one step beyond the current practice of approving or disapproving a tree planting or removal request.

3) Engagement of public input and participation on the plan according to local community needs. 
Although each of the cities in this study did perform a citizen survey, and in some cases provided public workshops to include citizens' input on the UFMP, none of the cities included a procedure whereby a local community could provide input and create a plan for their local neighborhood. For local residents, citizen tree planting projects provide for rapid transformation of their neighborhood. This plan could evolve through the nonprofit in each city or through a neighborhood initiative. However, no methodology was listed in any of the plans on how to achieve this. Recommendation: Each UFMP should include a neighborhood tree initiative. A method needs to be established for how a local neighborhood could engage municipal staff in designing and implementing a tree planting project. Cities should partner with community activists and train them in return for commitment to care and maintenance activities. This builds on the fact that local people know their local neighborhoods and care about these areas in ways that outsiders do not. This would also enhance the strategy of each plan in addressing communication and building community partnerships.

\section{4) Develop strategic partnerships between public and private sectors to create} support for urban forestry through services, materials, and corporate sponsorships.

There has been a development in understanding that to make sustainable progress in urban infrastructure programs, there needs to be collaboration among citizens, organizations, governments, industry, and the corporate community. This collective impact requires the commitment of all participants to have a shared vision, with a 
common understanding of the initiative and a joint approach to work on it through agreed-upon actions.

Recommendation: Part of the urban plan should include a methodology either through nonprofits or the neighborhood initiative - of partnerships with local civic organizations and corporate sponsors. Community stewardship and environmental volunteer work increase employees' morale and support companies in achievement of their corporate social responsibility goals. A strategic plan for corporate involvement in tree planting and care should be implemented into the UFMP for involvement of this important resource. This could change the street tree footprint to include corporate campus areas.

5) Establish access equally to urban forestry so neighborhoods of all nationalities, locations, and sizes can obtain the benefits of a green community.

There are economically disadvantaged communities in each of the three cities studied. Only one city mentioned a plan to target planting projects in low income areas. Projects that promote urban forestry often do not take place in low-income and minority communities. This is typically due to lack of organization and support. By considering urban forestry as a method of overcoming environmental injustice, this proposal calls for equitable distribution of urban trees and green space to communities of lower socio-economic status.

Recommendation: Each UFMP should include a strategic goal to identify and plan for urban forestry in low income parts of their communities. The plan should encourage collaboration with low income communities and landlords to build support for green infrastructure and secure local involvement. The plan should 
indicate sustainable measures, including job creation, local economic development, health benefits, pollution reduction, and community involvement.

\section{Implications for Urban Forestry Management in Santa Clara County}

This study presents an analysis of the first urban forest management plans created in Santa Clara County. Each city has its own history of tree management and is at a different stage of urban forest development. The recommended components propose a framework for how a comprehensive plan should be addressed, but it does not advocate specific objectives that should be included. Each plan should be a distinctive project, reflecting the unique character of that city's urban forest, community values, and management objectives. Therefore, the structure presented here is suggested to provide a guide to UFMP development. This study gives the cities of Santa Clara County a method of comparing their UFMP to other cities in the county. Illustrations of how municipalities manage different components of their UFMP can also be helpful to other cities, presenting a number of ways UFMPs have been applied, plan components, and concepts for strategic planning.

The results from this analysis offer CALFIRE’s Urban and Community Forestry Program manager's information to consider when awarding Urban and Community Forestry Program Greenhouse Gas Reduction Fund Grants (GGRF) in the future. The analysis of the components missing from the UFMPs provides useful information to lead CALFIRE's message to cities considering developing or updating an UFMP. The best forest urban management plan practices benchmarking scoring tool (Table 9) can be used as a model for municipalities to consult when developing an UFMP.

The National Arbor Day Foundation (NADF) already requires that cities create an advisory board, spend a minimum per capita on tree management, celebrate Arbor Day, and adopt a tree 
ordinance; however, neither the NADF nor CALFIRE have developed guidelines for creating a comprehensive plan. CALFIRE might perhaps consider adopting an UFMP framework with a set of criteria, necessitating that each UFMP funded through a CALFIRE grant address each measure. This would be a way to improve the comprehensiveness of Santa Clara County's UFMPs. The structure of comprehensive UFMP, which is presented in this study, can serve this purpose. 


\section{Literature Cited}

American Public Works Association. (2015). Urban forestry best management practices for public works managers, urban forest management plan. Retrieved from https://www2.apwa.net/Documents/About/CoopAgreements/UrbanForestry/UrbanForestry4.pdf.

American Public Works Association. (2015). Urban Forestry Best Management Practices for Public Managers, Budgeting and Funding. Retrieved from https://www2.apwa.net/Documents/About/CoopAgreements/UrbanForestry/UrbanForestry1.pdf.

Arbor Day Foundation. (2016). Learn about Tree City USA, Retrieved from https://www.arborday.org/programs/treecityusa/about.cfm

Bernhardt, E., Swiecki, T. J., Dunn, L., \& Works, P. (2014). City of Sunnyvale Urban Forest Management Plan-2014. Retrieved from:

http://sunnyvale.ca.gov/Portals/0/Sunnyvale/DPW/Trees/Urban\%20Forest\%20Mgmt\%20Pl an\%20-\%20Web.pdf.

California Urban Forests Council. (2015). About. Retrieved from http://investfromthegroundup.org/

CALFIRE (2014) Urban and Community Forestry Program Greenhouse Gas Reduction Fund Grants. Retrieved from:

http://www.fire.ca.gov/resource_mgt/downloads/CALFIRE_UF_ManagementActivitiesRFP 2014_2015.pdf.

City of Mountain View. (2014). Community Tree Master Plan, Retrieved from http://www.mountainview.gov/depts/cs/parks/community_tree_master_plan.asp.

City of Mountain View, (2016) Previous City Budgets, FY2014-15 Adopted Budget, Retrieved from http://www.mountainview.gov/depts/fasd/budget/archive.asp

City of Palo Alto. (2015). 2015 Palo Alto Strategic Forest Master Plan. Retrieved from http://www.cityofpaloalto.org/gov/depts/pwd/trees/mgmt/ufmp.asp

City of Palo Alto. (2015) City of Palo Alto, Budget in Brief, Fiscal year 2015. Retrieved from: http://www.cityofpaloalto.org/civicax/filebank/documents/44333

City of Palo Alto (2016) FY2016 Adopted Operating Budget_City Dept Budgets, Retrieved from: http://www.cityofpaloalto.org/gov/depts/asd/budget.asp\#2\%20-\%202016\%20\%202011\%20City\%20Budgets 
City of Sunnyvale, (2016) Budget documents, FY 2014-15Adopted Volume I Operating Budget, Retrieved from: http://sunnyvale.ca.gov/Departments/Finance/BudgetDocuments.aspx

City of Sunnyvale, (2016) Budget documents, FY 2014-15Adopted Volume II Operating Budget, Retrieved from: http://sunnyvale.ca.gov/Departments/Finance/BudgetDocuments.aspx

City of San Jose. (2016). City of San Jose tree policy manual \& recommended best management practices. Retrieved from http://www.sanjoseca.gov/DocumentCenter/View/8968

Clark, J. R., Matheny, N. P., Cross, G., \& Wake, V. (1997). A model of urban forest sustainability. Journal of Arboriculture, 23, 17-30.

Climate Registry. (2016), Taking action on climate change, Retrieved from: http://www.climateregistry.org/

Climate Action Reserve, (2016) Urban Forest Project Protocol, Projects. Retrieved from: https://thereserve2.apx.com/myModule/rpt/myrpt.asp?r=111

Conway, T. M., Urbani, L. (2007). Variations in municipal urban forestry policies: A case study of Toronto, Canada. Urban Forestry \& Urban Greening, 6(3), 181-192.

County of Santa Clara. (2015). About the County. Retrieved from https://www.sccgov.org/sites/scc/pages/about-the-county.aspx

Crompton, J. L. (2000). The impact of parks and open space on property values and the property tax base. Division of Professional Services, National Recreation \& Park Association. Retrieved from http://catalog.hathitrust.org/Record/010024155

DeepRoot Green Infrastructure. (2016). Silva Cell 2 Overview. Retrieved from http://www.deeproot.com/products/silva-cell/landing-page/silva-cell-2/overview

Denig, B.R. (2014). Ithaca's Trees: Master Plan, Inventory, \& Arboricultural Guidelines for the Public Trees of the City of Ithaca, New York. Retrieved from http://www.hort.cornell.edu/uhi/outreach/pdfs/Ithacas-Trees.pdf.

Donovan, G. H., \& Butry, D. T. (2009). The value of shade: Estimating the effect of urban trees on summertime electricity use. Energy and Buildings, 41(6), 662-668.

Haq, S. M. A. (2015). Urban green spaces and an integrative approach to sustainable environment. Urban Ecology: Strategies for Green Infrastructure and Land Use, 147. 
Kenney, W. A., van Wassenaer, P. J. E., \& Satel, A. L. (2011), Criteria and indicators for strategic urban forest programming and management. Arboriculture \& Urban Forestry, 37(3), 108117.

Kuhns, M. R., Lee, B., \& Reiter, D. K. (2005). Characteristics of urban forestry programs in Utah, U.S. Journal of Arboriculture, 31(6), 285.

Gulick, J. (2015) Funding your urban forest program, A guide for new and seasoned city foresters. Retrieved from: http://www.urban-forestry.com/assets/documents/funding-your-uf-programjenny-gulick.pdf.

Housholder, M. (2013). A carbon market primer. American Forests. Retrieved from http://www.americanforests.org/blog/a-carbon-market-primer/

International Society of Arboriculture. (2016). Certification. Retrieved from http://www.isa-arbor.com/certification/becomeCertified/index.aspx

Kielbaso, J, \& Cotrone, V., (1989). The state of the urban forest. Proceedings of Fourth Urban Forestry Conference. St. Louis 1989.p. 11-18.

Kuhns, M. R., Lee, B., \& Reiter, D. K. (2005). Characteristics of urban forestry programs in Utah, US. Journal of Arboriculture, 31(6), 285.

Little, J.B. (2012), The Future of urban forests in California's cap \& trade market, Retrieved from: http://californiareleaf.org/newsletters/newsletter-summer-2012/2/

Maas, J., Verheij, R. A., Groenewegen, P. P., De Vries, S., \& Spreeuwenberg, P. (2006). Green space, urbanity, and health: how strong is the relation?. Journal of epidemiology and community health, 60(7), 587-592.

Mathison, S. (Ed.). (2005). Encyclopedia of evaluation. Thousand Oaks, CA: Sage Publications, Inc. doi: http://dx.doi.org/10.4135/9781412950558

McPherson, E. G., \& Young, R. (2010). Understanding the challenges of municipal tree programming. Arborist News. Retrieved from http://www.fs.fed.us/psw/publications/mcpherson/psw_2010_mcpherson007.pdf

McPherson, E. G. (2000). Urban forestry issues in North America and their global linkages. Presentation for the 20th Session of the North American Forestry Commission Food and Agriculture Organization of the United Nations, St. Andrews, New Brunswick, Canada, 1216. 
McPherson, E. G., Simpson, J. R., Peper, P., Gardner, J., Vargas, S. L., Kelaine, E. and Xiao Qingfu. (2007). Northeast community tree guide: Benefits, costs and Strategic programming. United States Department of Agriculture, General Technical Report PSWGTR-202. Retrieved from http://www.treesearch.fs.fed.us/pubs/28759

National Oceanic and Atmospheric Administration. (2015). What is LIDAR? Retrieved from: http://oceanservice.noaa.gov/facts/lidar.html

Nowak, D. J. (2002). The effects of urban trees on air quality. Syracuse, NY: USDA Forest Service. Retrieved from www.ncufc.org/uploads/nowak trees.pd

Nowak, D. J., \& Crane, D. E. (2002). Carbon storage and sequestration by urban trees in the USA. Environmental Pollution,_116, 381-389. Retrieved from http://www.nrs.fs.fed.us/pubs/5521

Nowak, D, J., Crane, D. E., \& Stevens, J. C. (2006). Air pollution removal by urban trees and shrubs in the United States. Urban Forestry \& Urban Greening, 4, 115-23. Retrieved from http://www.fs.fed.us/ne/newtown_square/publications/other_publishers/OCR/ne_2006_now $\underline{\text { ak001.pdf }}$

Phytosphere Research. (2013). Name of Report. Retrieved from URL.

Pincetl, S. D. (2010). Implementing municipal tree programming: Los Angeles Million-Tree Initiative. Environmental Management, 45, 227-228. Retrieved from http://link.springer.com/article/10.1007/s00267-009-9412-7/fulltext.html

Pokorny, J., O'Brien, J., Hauer, R., Johnson, G., Albers, J., Bedker, P., \& Mielke, M. (2003). Urban tree risk management: A community guide to program design and implementation. Retrieved from http://www.treesearch.fs.fed.us/pubs/viewpub.jsp?index=11070

Schwab, J, C. (2009). Programming the urban forest: Ecology, Economy and Community Development. Report 555. Chicago, IL: American Programming Association. Retrieved from https://www.programning.org/research/forestry/report.htm

Sherer, P. M. (2003). Why America needs more city parks and open space. The Trust for Public Land.

Simpson, J. R., \& McPherson, E. G. (1996). Potential of tree shade for reducing residential energy use in California. Journal of Arboriculture, 22, 10-18.

Stigarll, A. \& Elam, E. (2009). Impact of improved landscape quality and tree cover on the price of single-family homes. Journal of Environmental Horticulture, 27(1), 24-30. 
Thompson, R., Pillsbury, N. H., \& Hanna, R. J. (1994). The elements of sustainability in urban forestry. The Department.

Thompson, R. P., \& Ahern, J. J. (2000). The state of urban and community forestry in California. Urban Forest Ecosystems Institute Technical Report\# 9, 1.

U.S. Forest Service, (2011). Urban Connections and Social Dynamics Program Charter, Pacific Southwest Research Station. Retrieved from: http://www.fs.fed.us/psw/programs/uesd/

U.S. Census (2016). The U.S. Census Bureau, Quick Facts, Mountain View, California. Retrieved from: http://www.census.gov/quickfacts/table/PST045215/0649670

U.S. Census (2016). The U.S. Census Bureau, Quick Facts, Palo Alto, California. Retrieved from http://www.census.gov/quickfacts/table/PST045215/0649670

U.S. Census (2016). The U.S. Census Bureau, Quick Facts, Sunnyvale, California. Retrieved from: http://www.census.gov/quickfacts/table/PST045215/0677000

U.S. Forest Service. (2015). i-Tree tools for assessing and managing community forests. Retrieved from https://www.itreetools.org/applications.php

U.S. Forest Service. (2015). About us. Retrieved from http://www.fs.fed.us/psw/about/

USDA Forest Service Southern Research Station. (2015). Urban forest sustainability and management audit system checklist process. Retrieved from http://www.srs.fs.usda.gov/compass/2015/04/22/urban-forestry-south-tests-new-urbanforest-sustainability-and-management-audit-system/

Vargas, K. (2011). Tools for the $21^{\text {st }}$ century. California Trees, a publication of California ReLeaf. Retrieved from http://californiareleaf.org/newsletter/

Wolf, K. L. (2005). Business district streetscapes, trees, and consumer response. Journal of Forestry, 103(8), 396-400. 